\title{
PERBANDINGAN RANCANGAN CAMPURAN BETON BERDASARKAN SNI 03-2834-2000 DAN SNI 7656:2012 PADA MUTU BETON 20 MPa
}

\author{
Yulius Rief Alkhaly \\ Jurusan Teknik Sipil Universitas Malikussaleh \\ Email: yr.alkhaly@gmail.com
}

\begin{abstract}
Abstrak
Sebelum keluarnya SNI 7656:2012, perancangan campuran beton normal dilakukan menurut SNI 03-2834-2000.Pada penelitian ini telah dilakukan suatu perbandingan rancangan terhadap kedua SNI tersebut pada mutu beton 20 MPa.Benda ujidigunakan berbentuk silinder dengan ukuran 150mm x 300mm, sebanyak 5 benda uji untuk masing-masing SNI.Hasil penelitian menunjukkan kuat tekanyang dihasilkan oleh SNI 2000 dan SNI 2012 berturut-turut: 21,95 MPa dan 23,01 MPa. Selanjutnya, nilai slump untuk kedua rancangan beton tersebut bertut-turut: $60 \mathrm{~mm}$ dan $70 \mathrm{~mm}$. Hasil inimemperlihatkan bahwa nilai kuat tekan yang diperoleh dari rancangan campuran berdasarkan SNI 2012 lebih tinggi dibanding nilai kuat tekan SNI 2000 dan keduanya memberikan nilai slump yang baik. Kedua SNI memberikan hubungan empiris dan relatif dari terhadap bahan beton dalam campuran, sehingga rancangan kadar bahan yang dihasilkan oleh masing-masing metode akan berbeda satu sama lain, yang pada akhirnya akan memberikan hasil kuat tekan yang berbeda pula.
\end{abstract}

Kata kunci: Campuran beton, kuat tekan, beton normal.

\section{Pendahuluan}

Beton normal merupakan jenis bahan konstruksi yang paling banyak digunakan, baik pada bangunan pemerintah maupun bangunan masyarakat. Secara enjinering, beton ini ditetapkan sebagai beton yang mempunyai kekuatan tekan antara $17 \mathrm{MPa}$ sampai $40 \mathrm{MPa}$ dan mempunyai berat isi $2200 \mathrm{~kg} / \mathrm{m}^{3}$ sampai dengan $2500 \mathrm{~kg} / \mathrm{m}^{3}$.

Guna menghasilkan beton normal, material yang umum digunakan berupa agregat alami (kerikil dan pasir) atau batu pecahyang berfungsi untuk pengisi dan pasta semen yang berfungsi untuk pengikat.Agregat merupakan produk alam yang memiliki beraneka ragam variasi mutu dan gradasi, oleh karenanyaagar dapat digunakan sebagai bahan pembentuk beton, agregat haruslah memenuhi persyaratan yang ditetapkan dalam suatu standar rancangancampuran beton (mix design).

Rancangan campuran beton merupakan suatu hal yang sangat kompleks.Banyak faktor yang mempengaruhi rancangan suatu campuran beton, antara lain: jenis struktur, mutu beton, kadar air, bentuk agregat, ukuran agregat maksimum, gradasi agregat, kadar semen, temperatur, umur pengujian, metoda pemadatan, kemudahan kerja (workability), durabilitas, bentuk dan ukuran benda uji. Pada dasarnya, masalah rancangan campuran beton adalah bagaimana memilih proporsi yang tepat dari semen, agregat halus, agregat kasar dan air untukmemproduksi beton yang memenuhi spesifikasi. 
Metode-metode mix design yang belaku pada tataran internasional semisal ACI (American Concrete Institute - Amerika), DOE (Department of Environment - Inggris), dan PCA (Portland Cement Association - Amerika) telah melalui suatu proses yang sangat panjang dan memerlukan biaya besar untuk penelitian (eksperimen) bertahun-tahun sehingga melahirkan metode yang disepakati dan menjadi standar acuan.

Pada tataran nasional, telah berlaku beberapa standar mix design mulai dari PBI 1971 N.I.-2, SNI 03-2834-1993, SNI 03-2834-2000 dan yang terkini SNI 7656:2012.Standar PBI 1971 dibuat mengacu pada CEB (Comité Européen du Beton) dan FIP (Fédération International de la Précontraint). SNI 03-2834-1993 dan SNI 03-2834-2000 mengacu pada DOE1975 (referensi 8).Selanjutnya SNI 7656:2012 merupakan adopsi modifikasi dari ACI 211.1-91 (referensi 1).

Dari uraian di atas diketahui bahwa adanya perbedaan metode antara standar SNI 03-2834-2000 (mengacu DOE) dan SNI 7656:2012 (mengacu ACI). Berdasarkan hal tersebut, tulisan ini akan membahas tentang perbandingan rancangan campuran beton normal antara SNI 03-2834-2000 (SNI 2000) dan SNI 7656:2012 (SNI 2012).Secara garis besar, metode SNI 2000 dan SNI 2012 didasarkan pada hubungan empiris, bagan, grafik, dan tabel. Meskipun kedua metode ini pada umumnyamengikuti prinsip dasar yang samadalam pemilihan parameter perancangan campuran, tetapi beberapa proseduralterdapat perbedaan.

\section{Tinjauan Kepustakaaan}

\subsection{Tujuan rancangan campuran beton}

Beton dikatakan sebagai suatu campuran dari empat bahan dasar terpisah, yaitu: semen, agregat kasar, agregat halus, dan air. Berdasarkandefinisilain, beton dapat juga dikatakan sebagai campuran bergradasi dari agregat halus dan agregatkasar yang direkatkan bersama-sama oleh pasta semen (Kett, I, 2010). Rancangan campuran beton ditujukan untuk memilih kombinasi yang paling ekonomis dan praktis dari tersediaan material lokal, tercapainyakemudahan kerja (workablity) yang diharapkan dalam keadaan plastis dan akanmemenuhi kualitas yang disyaratkan ketika mengeras (Day, K., W., 2006).

Beberapa pertimbangan yang harus terpenuhi dari sebuah campuran beton, berupa: kekuatan, durabilitas, impermeabilitas, kemudahan kerja (workability), stabilitas dimensi, penampilan yang baik, dan ekonomis (Day, K., W., 2006).

\subsection{Prosedur Rancangan Campuran}

\subsubsection{Prosedur SNI 03-2834-2000}

Gambar 1 merangkum langkah-langkah rancangan menggunakan metodeSNI 2000, metode ini mengadopsi beberapa asumsi sebagai berikut:

a. Metode ini berlaku untuk Ordinary Portland Cement (tipe I), RapidHardening Portland Cement (tipe II), High Early Strength Cement (tipe III), dan Sulphate Resisting Portland Cement (tipe V);

b. Metode ini membedakan antara agregat pecah (batu pecah) dan tidak dipecah (agregatalami/kerikil) yang akan mempengaruhi jumlah penggunaan air; 
c. Memperhitungkan gradasi dari agregat halus berdasarkan zonadan menganggap gradasi dari agregat halus akan mempengaruhi tingkat kemampuan kerja dari campuran beton;

d. Rasio optimum dari volume curah agregat kasar per kubik beton tergantung dari ukuran maksimum nominal dari agregat kasar dan gradasi agregat halus;

e. Kadar air dalam campuran beton hanya dipengaruhi oleh tingkat kemudahan kerja yang diperlukan, dinyatakan dengan ujislump atau uji VeBe;

f. Ukuran maksimum nominal dari agregat kasar, dianggap tidak mempengaruhi proporsi campuran;

g. Metode mengadopsi campuran beton hipotesisdengan rasio air semen (fas) 0,5 .

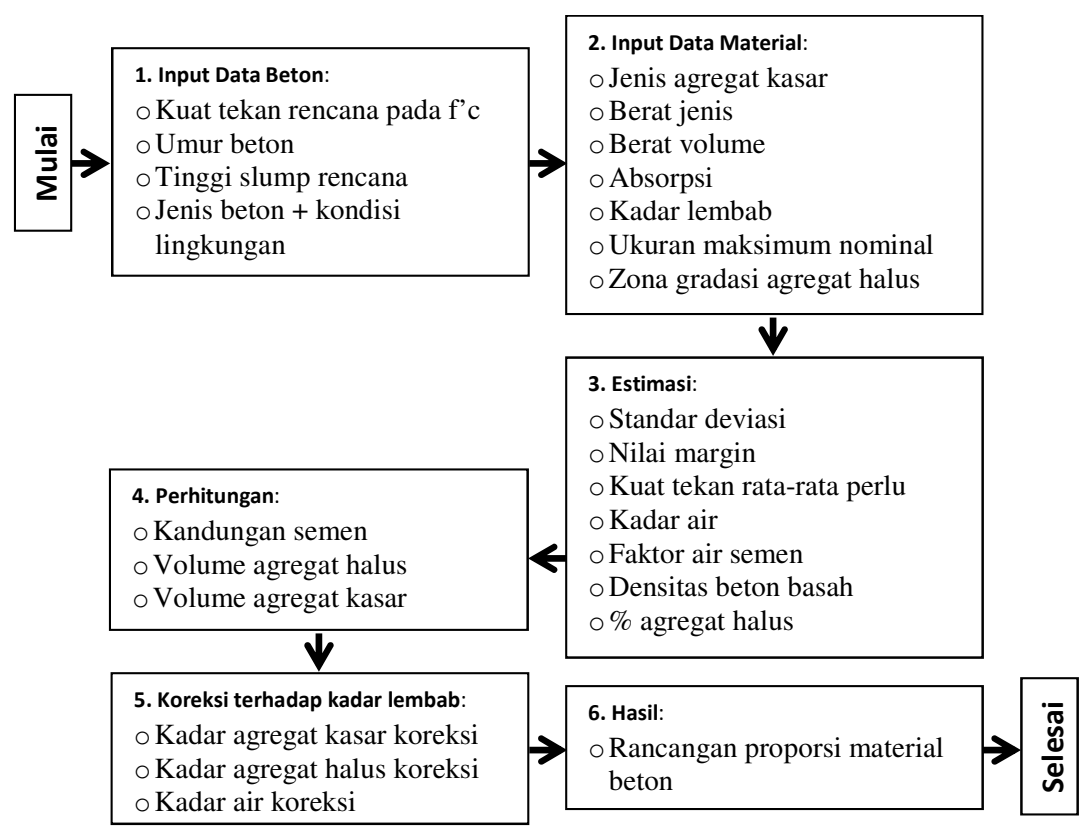

Gambar 1 Langkah-langkah rancangan campuran beton SNI 2000

\subsubsection{Prosedur SNI 7656:2012}

Gambar 2 memperlihatkan langkah-langkah perancangan beton berdasarkan SNI 2012, metode dalam SNI ini mengadopsi beberapa asumsi sebagai berikut:

a. Metode ini tidak membedakan jenis semen hidrolik (berlaku untuk semua jenis semen hidrolik) dan jenis agregat;

b. Konsistensi campuran yang mempengaruhi kemudahan kerjadianggap hanya tergantung pada kadar air bebas dari proporsi campuran, dinyatakan dalam uji slump, uji VeBe atau uji faktor pemadatan;

c. Rasio optimum dari volume curah agregat kasar per kubik beton tergantung hanya pada ukuran maksimum nominal agregat kasar dan gradasi agregat halus;

d. Jenis pemadatan berpengaruh pada tinggi slump yang dianjurkan;

e. Estimasi volume bahan campuran beton dapat dilakukan berdasarkan ekivalensi berat maupun ekivalensi volume absolut; 
f. Metode ini tidak memberikan batasan kadar minimum beton yang dapat digunakan;

g. Metode ini memberikan pengurangan air sebesar $18 \mathrm{~kg} / \mathrm{m}^{3}$ pada campuran beton yang menggunakan agregat kasar alami/kerikil.

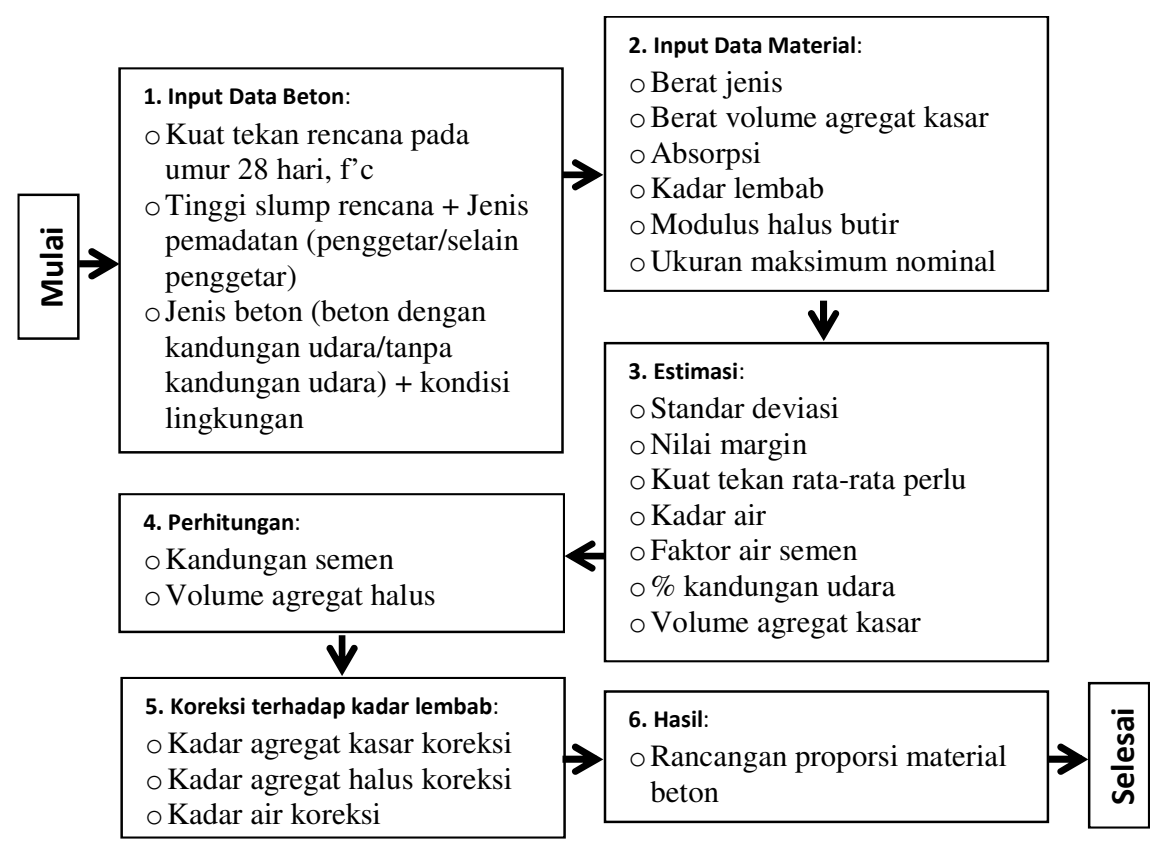

Gambar 2 Langkah-langkah rancangan campuran beton SNI 2012

\section{Metode Penelitian}

\subsection{Parameter Rancangan}

Material yang digunakan dalam penelitian ini adalah semen portland tipe Iyang telah memenuhi SNI 15-2049-2004 produksi PT. Semen Andalas Indonesia. Pasir yang digunakan berasal dari Krueng Mane, dan kerikil berasal dari Kuta Blang, Kabupaten Aceh Utara. Air adukan beton berasal dari Laboratorium Teknik Sipil, Universitas Malikussaleh.

Data material hasil pengujian di laboratorium dan parameter lain yang digunakan dalam rancangan beton diperlihatkan sebagaimana Tabel 1 berikut:

Tabel 1 Parameter rancangan campuran beton

\begin{tabular}{|c|c|c|c|}
\hline No. & \multicolumn{2}{|c|}{ Parameter } & Data \\
\hline 1 & \multicolumn{2}{|c|}{ Kuat tekan rencana, f'c (MPa) } & 20 \\
\hline 2 & \multicolumn{2}{|l|}{ Tipe semen } & Semen Portland, tipe I \\
\hline 3 & \multicolumn{2}{|c|}{$\begin{array}{l}\text { Ukuran maksimum nominal } \\
\text { agregat kasar (mm) }\end{array}$} & 19 \\
\hline 4 & \multicolumn{2}{|c|}{ Jenis agregat halus } & Pasir sungai \\
\hline 5 & \multicolumn{2}{|c|}{ Jenis agregat kasar } & Kerikil sungai \\
\hline \multirow{3}{*}{6} & \multirow{3}{*}{ Berat jenis } & Semen & 3,02 \\
\hline & & Pasir (SSD) & 2,52 \\
\hline & & Kerikil (SSD) & 2,60 \\
\hline
\end{tabular}




\begin{tabular}{|c|l|l|c|}
\hline \multirow{2}{*}{7} & \multirow{2}{*}{ Berat volume $\left(\mathrm{kg} / \mathrm{m}^{3}\right)$} & Pasir (padat) & 1524 \\
\cline { 3 - 4 } & & Kerikil (padat) & 1667 \\
\hline \multirow{2}{*}{8} & \multirow{2}{*}{ Modulus halus butir } & Pasir & 2,31 \\
\cline { 3 - 4 } & & Kerikil & 2,07 \\
\hline \multirow{2}{*}{9} & \multirow{2}{*}{\begin{tabular}{l} 
Kadar kelembaban \\
\cline { 3 - 4 }
\end{tabular}} & Pasir & 1,28 \\
\cline { 3 - 4 } 10 & \multirow{2}{*}{ Absorbsi $(\%)$} & Kerikil & 1,30 \\
\cline { 3 - 4 } & & Pasir & 4,14 \\
\hline 11 & Slump rencana $(\mathrm{mm})$ & & 1,76 \\
\hline 12 & Bahan tambah kimia & $25-125$ \\
\hline
\end{tabular}

\subsection{Analisa Saringan Agregat}

Hasil analisa saringan terhadap agregat halus dan agregat kasar diperlihatkan pada tabel berikut:

Tabel 2 Analisa saringan agregat

\begin{tabular}{|c|c|c|}
\hline \multirow{2}{*}{$\begin{array}{c}\text { Ukuran saringan } \\
(\mathrm{mm})\end{array}$} & \multicolumn{2}{|c|}{ \% Loloskomulatif } \\
\cline { 2 - 3 } & Pasir & Kerikil \\
\hline 38,10 & - & 100,00 \\
\hline 19,00 & - & 100,00 \\
\hline 12,7 & - & 58,74 \\
\hline 9,50 & 100,00 & 32,44 \\
\hline 4,75 & 100,00 & 1,50 \\
\hline 2,36 & 94,67 & - \\
\hline 1,18 & 80,60 & - \\
\hline 0,6 & 51,15 & - \\
\hline 0,3 & 22,44 & - \\
\hline 0,15 & 20,34 & - \\
\hline Modulus halus butir & 2,31 & 2,07 \\
\hline Zona butiran & - & II \\
\hline
\end{tabular}

\subsection{Benda Uji Beton}

\subsubsection{Komposisi Campuran}

Rancangan campuran beton normal f'c $20 \mathrm{MPa}$ untuk masing-masing SNI dilakukan sesuai dengan parameter material yang sama sebagaimana Tabel 2 di atas.Hasil rancangan komposisi campuran beton (mix design) mengacu pada SNI 2000 dan SNI 2012 (volume absolut) diperlihatkan pada Tabel 3 berikut:

Tabel 3 Komposisi material per $\mathrm{m}^{3}$ beton

\begin{tabular}{|c|c|c|c|c|c|c|c|}
\hline \multirow[b]{2}{*}{ Jenis beton } & \multirow[b]{2}{*}{ Kode } & \multicolumn{5}{|c|}{ Berat material untuk volume $1 \mathrm{~m}^{3}$} & \multirow{2}{*}{$\begin{array}{c}\text { Jumlah } \\
\text { sampel } \\
\text { (bh) }\end{array}$} \\
\hline & & $\begin{array}{c}\text { Semen } \\
(\mathrm{Kg})\end{array}$ & $\begin{array}{l}\text { Pasir } \\
(\mathrm{Kg})\end{array}$ & $\begin{array}{c}\text { Kerikil } \\
(\mathrm{Kg})\end{array}$ & $\begin{array}{l}\text { Air } \\
(\mathrm{Kg})\end{array}$ & $\begin{array}{c}\text { Jumlah } \\
(\mathrm{kg})\end{array}$ & \\
\hline $\begin{array}{c}\text { SNI-2002 } \\
20 \mathrm{MPa} \\
\end{array}$ & B20A & 403,00 & 701,25 & 1023,36 & 220,38 & 2347,99 & 5 \\
\hline $\begin{array}{c}\text { SNI-2012 } \\
20 \mathrm{MPa} \\
\end{array}$ & B20B & 322,00 & 671,49 & 1114,30 & 211,02 & 2318,81 & 5 \\
\hline
\end{tabular}




\subsubsection{Penyiapan dan Perawatan Benda Uji}

Pengadukan dilakukan menggunakan molen laboratorium kapasitas kecil bertipe drum.Benda uji dicor menggunakan cetakan silinder baja standar berukuran $150 \mathrm{~mm}$ x $300 \mathrm{~mm}$ sebanyak 5 benda uji untuk masing-masing jenis beton. Pemadatan dilakukan dengan batang penumbuk pada 3 lapisan, yang masing-masing lapisan ditumbuk sebanyak 25 kali. Setelah berumur 4 jam, permukaan benda uji diberi lapisan kaping pasta semen agar menjadi rata dan halus. Pada saat umur benda uji mencapai 24 jam, cetakan baja dilepas, kemudian dilakukan perawatan dengan cara perendaman dalam air pada suhu ruangan selama 28 hari.

\subsubsection{Prosudur uji tekan}

Pengujian kuat tekan dilakukan dengan mesin uji tekan hidrololik berkapasitas $2000 \mathrm{kN}$ merek Tatonas (Gambar 3) yang telah dikalibrasi oleh KAN (Komite Akreditasi Nasional) Indonesia. Pengujian ini dilakukan pada umur benda uji 28 hari. Pengujian kuat tekan dilakukan sesuai dengan ketentuan dalam SNI 03-1974-1990.

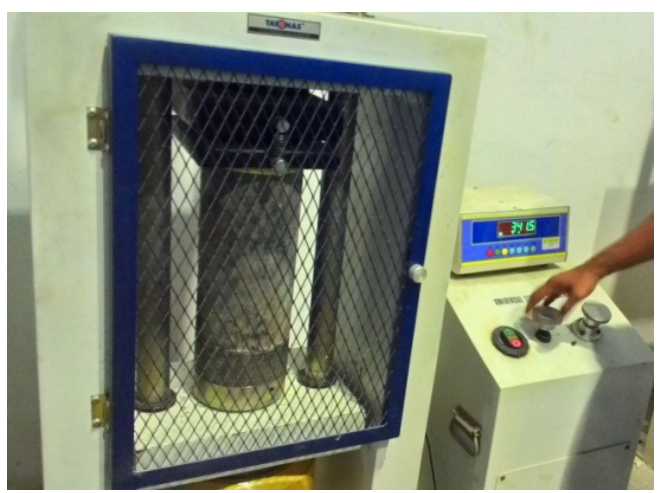

Gambar 3. Mesin uji tekan

\section{$4 \quad$ Hasil dan Pembahasan}

\subsection{Perbandingan Umum Hasil Rancangan}

Berdasarkan langkah-langkah perancangan campuran beton dapat dibandingkan beberapa hal, yaitu:

a. Medode dalam SNI 2000 lebih komprehensif dalam memperhitungkan hubungan empiris kadar semen, kadar air dan kadar agregat, sedangkan SNI 2012 lebih sederhana dan praktis.

b. Untuk rancangan campuran yang tidak menggunakan standar deviasi dari pengujian sebelumnya, SNI 2000 memberikan nilai margin (m) sebesar 12, sedangkan SNI 2012 memberikan nilai margin (m) sebesar 7 (nilai ini disyaratkan dalam SNI 2847:2013). Dari Tabel 5, terlihat bahwa hasil uji kuat tekan dari kedua SNI tidak mencapai kuat tekan rata-rata perlu (f'cr), namun kuat tekat disyratkan (f'c) terpenuhi.

c. Hasil rancangan berdasarkan SNI 2000 memberikan kadar semen, kadar pasir, dan kadar air lebih banyak dibanding SNI 2012. 


\subsection{Perbandingan Tinggi Slump Campuran}

Pengukuran slump dilakukan menggunakan kerucut Abram.Pengujian ini ditujukan untuk mengetahui kekentalan (konsistensi dan kohesi) dan kemudahan kerja (workability) dari adukan beton basah dengan yang ditunjukkan oleh nilai slump.Hasil pengukuran tinggi slump untuk masing-masing jenis beton adalah sebagai berikut:

Tabel 4 Nilai slumpadukan beton

\begin{tabular}{|c|c|c|c|}
\hline No & Jenis beton & Kode & $\begin{array}{c}\text { Rerata tinggi } \\
\text { slump }(\mathrm{mm})\end{array}$ \\
\hline 1 & SNI-2002, 20 MPa & B20A & 60 \\
\hline 2 & SNI-2012, 20 MPa & B20B & 70 \\
\hline
\end{tabular}

Dari Tabel 4 memperlihatkan bahwa nilai slump untuk kedua jenis beton basah memenuhi syarat slump rencana $25 \mathrm{~mm}-125 \mathrm{~mm}$, dengan demikian kekentalan (konsistensi dan kohesi) dan kemudahan kerja (workability) cukup baik untuk kedua campuran.

\subsection{Perbandingan Berat Sampel dan Kuat Tekan}

Tabel 5 memperlihatkan hasil pengujian kuat tekan beton rata-rata untuk 5 benda uji silinder beton untuk masing-masing SNI.

Tabel 5 Berat dan kuat tekan masing-masing sampel beton

\begin{tabular}{|c|c|c|c|c|c|c|c|c|}
\hline $\begin{array}{l}\text { Kode } \\
\text { jenis } \\
\text { beton }\end{array}$ & $\begin{array}{c}\text { Kuat tekan } \\
\text { disyaratkan, } \\
\text { f'c } \\
(\mathrm{MPa})\end{array}$ & $\begin{array}{l}\text { Kuat tekan } \\
\text { rata-rata } \\
\text { perlu, f'cr } \\
(\mathrm{MPa})\end{array}$ & $\begin{array}{l}\text { No } \\
\text { uji }\end{array}$ & $\begin{array}{c}\text { Berat } \\
\text { sampel } \\
(\mathrm{Kg})\end{array}$ & $\begin{array}{l}\text { Rerata } \\
\text { berat } \\
\text { sampel } \\
(\mathrm{Kg})\end{array}$ & $\begin{array}{c}\text { Kuat } \\
\text { tekan } \\
(\mathrm{MPa})\end{array}$ & $\begin{array}{c}\text { Standar } \\
\text { deviasi } \\
\text { kuat } \\
\text { tekan }\end{array}$ & $\begin{array}{c}\text { Rerata } \\
\text { kuat } \\
\text { tekan } \\
(\mathrm{MPa}) \\
\end{array}$ \\
\hline \multirow{5}{*}{ B20A } & \multirow{5}{*}{20} & \multirow{5}{*}{32} & 1 & 12,54 & \multirow{5}{*}{12,46} & 23,20 & \multirow{5}{*}{1,22} & \multirow{5}{*}{21,95} \\
\hline & & & 2 & 12,42 & & 20,37 & & \\
\hline & & & 3 & 12,32 & & 21,50 & & \\
\hline & & & 4 & 12,52 & & 21,50 & & \\
\hline & & & 5 & 12,51 & & 23,20 & & \\
\hline \multirow{5}{*}{ B20B } & \multirow{5}{*}{20} & \multirow{5}{*}{27} & 1 & 12,53 & \multirow{5}{*}{12,41} & 22,62 & \multirow{5}{*}{0,78} & \multirow{5}{*}{23,01} \\
\hline & & & 2 & 12,45 & & 21,87 & & \\
\hline & & & 3 & 12,10 & & 23,21 & & \\
\hline & & & 4 & 12,45 & & 23,58 & & \\
\hline & & & 5 & 12,53 & & 23,79 & & \\
\hline
\end{tabular}

Rancangan yang dibuat berdasarkan keduaSNImenghasilkan kuat tekan pada umur 28-hari lebih tinggi dari kuat tekan yang disyaratkan. Nilai deviasi standar dari pengujian dengan SNI 2000 menunjukkan indikator hasil pengujian yang sangat baik, sedang pengujian dengan SNI 2012 menunjukkan indikator hasil pengujian yang istimewa.

Hasil rancangan campuran SNI 2012 memberi hasil kuat tekan lebih tinggi dan berat sampel lebih rendah dibandingkan dengan metode SNI 2000. Dari segi perbandingan kandungan pasta semen (semen + air) terhadap kandungan agregat (pasir + kerikil), dari Tabel 3 terlihat bahwa SNI 2000 memiliki rasio 1:2,67 dan SNI 2012 berrasio 1:3,35 berdasarkan berat. Hal ini menunjukkah bahwa kontribusi kadar agregat kasar berpengaruh pada nilai kuat tekan beton. 


\section{Kesimpulan dan Saran}

\subsection{Kesimpulan} berikut:

Dari uraian di atas maka dapat diambil beberapa kesimpulan sebagai

a. Kedua metode desain campuran beton memberikan hubungan empirisdan relatif dari terhadap bahan beton dalam campuran, sehingga rancangan kadar bahanyang dihasilkan oleh masing-masing metode akan berbeda satu sama lain, yang pada akhirnya akan memberikan hasil kuat tekan yang berbeda pula;

b. Kedua metode desain campuran beton memberikan nilai slump yang menunjukkan bahwa campuran beton memiliki kemudahan untuk: diaduk, dicor, dipadatkan, dan dilakukan penyelesaian akhir.

\subsection{Saran}

Pada penelitian ini hanya dibandingkan rancangan beton pada mutu $20 \mathrm{MPa}$, nilai slump, dan sifat mekanis kuat tekan saja, maka perlu adanya kajian lebih komprehensif terhadap mutu beton dan sifat mekanis beton yang lain. Selanjut diperlukan pula kajian tentang perbandingan harga produksi setiap $1 \mathrm{~m}^{3}$ campuran beton.

\section{Daftar Kepustakaan}

ACI Committee 211, 1991, ACI 211.1-91:Standard Practice for Selecting Proportions for Normal, Heavyweight, and Mass Concrete, American Concrete Institute, United States;

Day, K., W., 2006, Concrete Mix Design,Quality Control andSpecification, edisi ke-3, Taylor \& Francis, London;

Anonim, 1990, SNI 03-1974-1990: Metode pengujian kuat tekan beton, Badan StandarisasiNasional Indonesia, Jakarta;

Anonim, 2000, SNI 03-2834-2000: Tata cara pembuatan rencana campuran beton normal, Badan Standarisasi Nasional Indonesia, Jakarta;

Anonim, 2004, SNI 15-2049-2004: Semen portland, Badan StandarisasiNasional Indonesia, Jakarta;

Anonim, 2012, SNI 7656:2012:Tata cara pemilihan campuran untuk beton normal,beton berat dan beton massa, Badan Standarisasi Nasional Indonesia, Jakarta;

Anonim, 2013, SNI 2847-2013:Persyaratan beton struktural untuk bangunangedung, Badan Standarisasi Nasional Indonesia, Jakarta;

Kett, I., 2010, Engineered Concrete: Mix Design and Test Methods, edisi ke-2, CRC Press, New York;

Teychenné, D. C., et al., 1975, Design of normalconcrete mixes, Department of the Environment, Construction Research Communications Ltd, London. 